\title{
Effect of selenium supplementation of the diet on wool production during pregnancy in Ossimi ewes
}

\author{
Elsherbiny A. A. ${ }^{\text {a }}$, Saudi E. M. ${ }^{\text {a }}$, ELbadawy A. A. ${ }^{\text {, }}$, Gheetas R. M. ${ }^{\text {a* }}$ \\ ${ }^{a}$ Animal Production Department, Faculty of Agriculture, Al-Azhar University, Cairo, Egypt \\ ${ }^{b}$ Animal Production Research Institute, Agricultural Research Center, Dokki, Giza, Egypt
}

\begin{abstract}
A trial was carried out on thirty pregnant Ossimi ewes aged 3-4 years, belonging to the Animal Production Research Station at Sids, with live weight ranging between 45 to $50 \mathrm{~kg}$. The animals were divided at randomly into 3 groups of 10 ewes each with almost equal mean live body weight. Animals were given maintenance and production diets according to their average body weight (NRC 1988). Concentrate feed mixture composed of $22 \%$ decorated cotton seed cake, $20 \%$ molasses, $44 \%$ wheat bran, $10 \%$ yellow maize, $2.5 \%$ ground limestone and $1.5 \%$ common salt. Water was provided ad-libitum during the whole experimental period with clover hay and rice straw. The trial started $1^{\text {st }}$ January and ended $1^{\text {st }}$ June 2018 (5 mo. /wool growth) and included 3 groups; Control group; received the basal diet only without any supplements, the first group; was given the basal diet plus $0.23 \mathrm{gm}$ selenoprotein / $\mathrm{kg}$ dry matter/ head/day ( $0.5 \mathrm{mg}$ available selenium), the second group; was given the basal diet plus $0.33 \mathrm{gm}$ selenoprotein $/ \mathrm{kg}$ DM $/$ head /day $(0.7 \mathrm{mg}$ available selenium). The trial included two periods, the first three months of pregnancy and the last two months of pregnancy. The aim of this study was to study the effect of adding selenium to the diet of pregnant Ossimi ewes on wool growth. Physical and mechanical wool properties were assessed besides estimation of Glutathione peroxidase (GPX) enzyme activity. Results showed that during the first 3 months of pregnancy, there was significant difference $(\mathrm{P} \leq 0.05)$ among groups in FD, SST, ELO \% and GPX enzyme activity, while there was no significant difference in STL. But in the last two months of pregnancy there was significant difference $(\mathrm{P} \leq 0.05)$ among groups in STL, FD, SST, ELO \% and GPX enzyme activity.
\end{abstract}




\section{Introduction}

Pregnancy is stressful period in the life of ewes with wool growth rates negatively affected as a result (Masters et al., 1993). The largest reduction in growth occurs in the last trimester of pregnancy, (Oddy and Annison, 1979). During pregnancy wool growth can be suppressed by 20-60 $\%$ (Corbett, 1979). Pregnancy influences various wool characteristics such as reducing fibre diameter, staple strength, fibre length and clean fleece weight (Masters et al., 1993). Selenium is essential for pregnant ewes to maintain normal physiological functions through its antioxidant properties, (Sordillo, 2013). The aim of this study was to determine wool production and characteristics of Ossimi ewes during pregnancy period and the effect of adding organic selenium to their diet on wool growth.

\section{Materials and methods}

Thirty pregnant Ossimi ewes, 3-4 years old, weighing 45 to $50 \mathrm{~kg}$, were divided at random into 3 equal groups of 10 ewes each of almost equal mean live body weight. Animals were given maintenance and production diet according to their average body weight, (NRC, 1988). Concentrate feed mixture composed of $22 \%$ undecorated cotton seed cake, $20 \%$ molasses, $44 \%$ wheat bran, $10 \%$ yellow corn, $2.5 \%$ ground limestone and $1.5 \%$ common salt. Water was provided adlibitum during the whole experimental period with clover hay and rice straw. The trial started $1^{\text {st }}$ of January and ended at $1^{\text {st }}$ of June 2018 and included 3 groups of ewes; Control group; received the basal diet only with no supplements, the first group; was given the basal diet supplemented with $0.23 \mathrm{gm}$ selenoprotein / $\mathrm{kg}$ dry matter/ head/day $(0.5 \mathrm{mg}$ available selenium), the second group; was given the basal diet supplemented with $0.33 \mathrm{gm}$ selenoprotein $/ \mathrm{kg} \mathrm{DM} / \mathrm{h} / \mathrm{d}$ $(0.7 \mathrm{mg}$ available selenium). Wool samples were shorn twice during the experimental period; the first was done on April $1^{\text {st }} 2018$ (3 months/growth), the second shearing was done on June $1^{\text {st }}$ 2018 ( $2 \mathrm{mo} . / \mathrm{g})$ and tattooed on the right mid side position $10 \times 10 \mathrm{~cm}\left(100 \mathrm{~cm}^{2}\right)$. The tattooed areas were shorn to the skin at the beginning of each period. Blood samples were collected twice times during the experimental period; at the same timing as the shorn wool. Ten $\mathrm{ml}$ blood samples were collected from ten ewes of each group to assess Glutathione peroxidase activity (GPX) in their plasma. Samples were taken via jugular venipuncture using 18 -gauge needles and $10 \mathrm{~mL}$ heparin vacutainers. Samples were centrifuged at $3500 \mathrm{rpm}$ for 15 minutes; the blood samples were frozen and kept for analysis. The physical measurements included weight of grease and clean wool samples, staple length and fibre diameter. The grease wool weight shorn of $100 \mathrm{~cm}^{2}$ of skin was weighed using a digital read out balance to the nearest $0.01 \mathrm{gm}$. Clean wool weight of $100 \mathrm{~cm}^{2}$ of shorn wool was found after extraction of residual grease by Soxhlet apparatus from scoured samples using ethyl ether b.p: 64 as a solvent. The clean wool percentage was then calculated from the yield of $100 \mathrm{~cm}^{2}$ samples as follows: Clean scoured yield $\%=$ Weight of scoured and dried sample / Weight of greasy sample $\times 100$. The 
contaminants percentage was calculated from the following equation: The grease sample weight - the clean sample weight / Grease sample weight $\times 100$. The yield was then calculated from the yield of 100 $\mathrm{cm}^{2}$ of shaved skin samples. Staple length was measured on 20 random staples from each sample, using a centigrade ruler to the nearest $0.25 \mathrm{~cm}$. The mean staple length was then calculated with the standard error for each treatment. Fibre diameter was measured in microns using Image analyzer software (Zen, 2012, Blue edition) and (device carl-Zeiss microimaging $G$ and bh) with lenses 10/0.847. Staple strength and elongation were measured on Staple strength was measured by the force required to break the staple in Newton and dividing this value by the thickness of the staple (mm) (Newton per kilotex, N/Ktex). Ten staples were chosen at random from each sample and prepared for measuring their strength using the Artiest Staple Breaker (Caffin, 1980). The length of the top and the base of each broken staple in the strength tester were measured and then calculated. The increase in the length as a proportion of the original staple length before testing was used to calculate the elongation percentage. Thus, the length of the top as a percentage from the length of both top and base was found as follows:

- Thickness of the staple (kilotex) = (weight of clean dry staple / length of staple) $\times 100$

- Staple Strength $(\mathrm{N} /$ Kilotex $)=$ strength (N) / thickness of staple (mm) (kilotex)

- The Elongation percent $=($ length of top +length of base) - staple length)/ staple length) $\times 100$.
Data were analyzed using general linear model (GLM) of SPSS program, (1999) (statistical product and service solutions). One -way analysis of variance (ANOVA) was adopted to study the effect of supplementing the diet of the experimental ewes with different levels of organic selenium (selenoprotein) at two stages (the $1^{\text {st }}$ three months of pregnancy and the last two months of pregnancy period) on wool production and growth. The following equation was used:

$x i j=\mu+\alpha i+e i j$

Where, $\mathrm{x}_{\mathrm{ij}}$ is the observed value of the trait. $\mu$ is the grand mean of the trait. $\alpha_{\mathrm{i}}$ is the effect of selenoprotein level $(i=1,2$, 3 ). eij is the experimental error assumed to be normally distributed with mean zero and variance of $\mathrm{V}^{2}$. Comparison among means was followed using Duncan's new multiple range test Duncan (1955).

\section{Results and Discussion}

Results in Table (1) showed that, wool weights varied among groups in either grease or clean weights wool of samples. The means of G.W.S were 15.40, 23.30 and 34.15 while the means of C.W.S were $9.95,16.30$ and $23.55 \mathrm{gm}$ for the control group, $0.5 \mathrm{mg}$ Se-supplemented group and $0.7 \mathrm{mg}$ Se-supplemented group respectively. It was clear in these experimental groups that the selenoprotein supplementation to the diet caused a substantial increase in clean weights of wool being greater in the third group (0.7 mg Se-supplemented group) during the $1^{\text {st }}$ three months of pregnancy 
followed by $0.5 \mathrm{mg}$ Se-supplemented group. In the same context Saudi, (2015) showed that, the addition of different levels of selenium $0.3,0.5$ and $0.7 \mathrm{mg}$ se/ $\mathrm{kg}$ dry matter to the diet of pregnant crossbred ewes significantly increased clean weight of wool $(\mathrm{P} \leq 0.05)$. Furthermore Saudi, (2018) showed that, the addition of selenium to the diet of pregnant Rahmani ewes significantly increased clean fleece weight $(\mathrm{P} \leq 0.05)$. Corbett (2000) showed that, there can be substantial reductions in wool growth rate during both the latter half of pregnancy and early lactation. Overall, reproduction usually reduces annual fleece growth of ewes by 10 to $14 \%$; the greatest reduction being for ewes rearing twins. This finding may benefit farmers because CFW is directly responsible for determining the commercial value of wool (Banks and Brown, 2009; Mortimer et al., 2010) as prices are related to the amount of wool fibre, such that higher prices are offered for wools with greater CFW yields (Johnson and Larsen, 1978; Snowder et al., 1997; Rogers and Schlink, 2010).

Table (1): Means of grease (G.W.S) and clean weights of wool samples (C.W.S) and percentage of contaminants in wool samples $(\mathrm{C} \%)$ during the first 3 months of pregnancy.

\begin{tabular}{lccc}
\hline Experimental groups & G.W.S $(\mathrm{gm})$ & C.W.S $(\mathrm{gm})$ & $\mathrm{C} \%$ \\
\hline Control group & 15.40 & 9.95 & 35.38 \\
\hline $0.5 \mathrm{mg}$ Se-supplemented & 23.30 & 16.30 & 30.04 \\
\hline $0.7 \mathrm{mg}$ Se-supplemented & 34.15 & 23.55 & 31.03 \\
\hline
\end{tabular}

Results in Table (2) show that, there were no significant differences $(\mathrm{p} \leq 0.05)$ among groups in staple length (STL) in the first 3 months of pregnancy period. The means of STL were 4.55, 4.65 and $5.60 \mathrm{~cm}$ for the control group, $0.5 \mathrm{mg} \mathrm{Se}-$ supplemented group and $0.7 \mathrm{mg} \mathrm{Se}$ supplemented group respectively. There was a slight increase in STL in comparison with the control group although it didn't reach significance. This result can be explained in light of the results of Morel and Barouki (1999) who clarified that, selenoproteins have key metabolic roles as antioxidants and affect the redox status of the cells. Selenoprotein supplementation to the diet of ewes increased wool growth according to the amount of amino acids that reach the intestine (Hynd and Allden, 1985) rather than energy supply (Black et al., 1973; Reis et al., 1992). Results in Table (2) also showed that, there were significant differences $(\mathrm{p} \leq 0.05)$ among groups in fibre diameter (FD). The means of FD were $32.40,36.65$ and $36.40 \mu \mathrm{m}$ for the control group, $0.5 \mathrm{mg} \mathrm{Se}$ supplemented group and $0.7 \mathrm{mg} \mathrm{Se}$ supplemented group respectively. It was clear from these results that $\mathrm{Se}$ supplementation to the diet caused a large increase in fibre diameter being greater in the second group $(0.5 \mathrm{mg} \mathrm{Se}-$ supplemented group), being $4.25 \mu \mathrm{m}$, while $0.7 \mathrm{mg}$ of selenium in the diet of the third group showed an increase in 
mean diameter of the fiber $4 \mu \mathrm{m}$ relative to the control group. Pregnancy and lactation are stressful periods in the life of sheep with wool growth rates negatively affected as a result (Masters et al., 1993). The largest reduction in growth occurs in the last trimester of pregnancy and during the first several weeks of lactation also known as the periparturient period. This difference is even more pronounced in twin bearing ewes (Oddy and Annison, 1979). During pregnancy and lactation wool growth can be suppressed by 20-60\% (Corbett, 1979). The suppression of wool growth in pregnant and lactating ewes is believed to be a result of competition for nutrients between metabolic processes (Oddy and Annison, 1979). Absorbed nutrients must be shared between the wool follicles, maternal tissues, the growing foetus and milk production with wool receiving very low percentages of this share (McNeil et al., 1997). Pregnancy and lactation influence various wool characteristics such as reducing fibre diameter, staple strength, fibre length and clean fleece weight (Masters et al., 1993). As these characteristics are only affected in the short term, i.e., the duration of pregnancy and lactation, variations are obtained along the wool staple. These variations ultimately affect the staple strength and therefore the processing quality of the raw wool reducing the price of the wool clip. Variations in wool growth rate commonly result in a reduction in staple strength. This reduction is due to changes in the physical properties of the wool such as a reduction in the minimum fibre diameter (Orwin et al., 1980) or an increase in the rate of change of fibre diameter (Hansford and Kennedy, 1990). Wool production, fibre growth rate and fibre diameter vary throughout the year due to combinations of many factors including the inherent wool growth rhythm due to photoperiod, seasonal management and feed supply, changes in physiological status such as pregnancy and lactation, occurrence of disease and parasite infestations (Butler, 1992).

Table (2): Means \pm standard errors of staple length (STL) and fibre diameter (FD) during the first three months of pregnancy.

\begin{tabular}{lll}
\hline Experimental groups & STL $(\mathrm{cm})$ & FD $(\mu \mathrm{m})$ \\
\hline Control group & $4.55 \pm 0.30^{\mathrm{a}}$ & $32.40 \pm 0.95^{\mathrm{b}}$ \\
\hline $0.5 \mathrm{mg}$ Se-supplemented & $4.65 \pm 0.25^{\mathrm{a}}$ & $36.65 \pm 0.45^{\mathrm{a}}$ \\
\hline $0.7 \mathrm{mg}$ Se-supplemented & $5.60 \pm 0.45^{\mathrm{a}}$ & $36.40 \pm 0.90^{\mathrm{a}}$ \\
\hline Means within columns with different superscripts are significantly different $(\mathrm{P} \leq 0.05)$.
\end{tabular}

Results in Table (3) showed that, there were significant differences $(\mathrm{p} \leq 0.05)$ among groups in staple strength (SST). The means of SST were 28.30, 33.95 and $36.15 \mathrm{~N} /$ Ktex for the control group, 0.5 mg Se-supplemented group and $0.7 \mathrm{mg}$ Se-supplemented group respectively. Selenium supplementation to the diet caused significant $(p \leq 0.05)$ increase in staple strength being greater in the third 
group (0.7 mg Se-supplemented group) during the $1^{\text {st }}$ three months of pregnancy. Various physiological and environmental factors are known to influence the strength of wool fibres, although the compositional and structural characteristics of the fibre that are associated with weakness are still poorly understood. The differences in staple strength can be regarded as an indication of large differences between sheep in the intrinsic strength of wool fibres comprised within the staple (Reis, 1992).
Also, there were significant differences $(p \leq 0.05)$ among groups in staple elongation percentage (ELO \%). The means of ELO \% were 18.10, 24.15 and $31.75 \%$ for the control group, $0.5 \mathrm{mg}$ Se-supplemented group and $0.7 \mathrm{mg} \mathrm{Se}-$ supplemented group respectively, it was clear in this experiment that $\mathrm{Se}$ supplementation to the diet caused a significant $\quad(p \leq 0.05) \quad$ increase in elongation percentage being greater in the $0.7 \mathrm{mg}$ Se-supplemented group during the $1^{\text {st }}$ three months of pregnancy.

Table (3): Means \pm standard errors of staple strength (SST) and elongation percentage (ELO \%) during the first three months of pregnancy.

\begin{tabular}{llc}
\hline Experimental groups & SST (N/Ktex) & ELO \% \\
\hline Control group & $28.30 \pm 0.80^{\mathrm{b}}$ & $18.10 \pm 1.75^{\mathrm{c}}$ \\
\hline $0.5 \mathrm{mg}$ Se-supplemented & $33.95 \pm 0.95^{\mathrm{a}}$ & $24.15 \pm 1.75^{\mathrm{b}}$ \\
\hline $0.7 \mathrm{mg}$ Se-supplemented & $36.15 \pm 0.70^{\mathrm{a}}$ & $31.75 \pm 0.75^{\mathrm{a}}$ \\
\hline Means within columns with different superscripts are significantly different $(\mathrm{P} \leq 0.05)$
\end{tabular}

During the first three months of pregnancy the level of glutathione peroxidase in the blood plasma showed the activity level of the enzyme which was parallel to the level of selenium in the diet. It was clear from Table (4) that, the ewes which received selenoprotein showed higher levels of glutathione activity $11.50 \pm 1.20$ and $8.55 \pm 0.50$ $\mu \mathrm{u} / \mathrm{ml}$ for group 3 and 2 compared to the control group $3.40 \pm 0.40 \mu \mathrm{u} / \mathrm{ml}$. It is well known that GPX is an enzyme naturally occurring-sulphur-amino acid tripeptide composed of L-cystiene, Lglutamic acid and glycine. Glutathione peroxidase has a serious role in the prevention and treatment of degenerative diseases and act as anti-oxidant and deactivator of free radicals (Rotruck et al., 1973). Selenium is also an essential element for the production of GPX. It is therefore reasonable to suggest that addition of selenoprotein to the diet of ewes caused a significant $(\mathrm{P} \leq 0.05)$ increase in the GPX activity which in turn would give some protection to the wool fibres from degradation. Selenium (Se) is an essential trace mineral for sheep and is involved in multiple metabolic pathways. It is an important component of the glutathione peroxidase enzyme (GPx), which generates defences against cellular oxidative damage. Not only restricted to an antioxidant role but is also a component of other selenoproteins, such as iodothyronine 
deiodinases, which are responsible for metabolism of thyroid hormones, and the enzyme thioredoxin reductase (TrxR), which reduces thioredoxin and are thus involved in many cell functions including cell growth, control of apoptosis and maintenance of cellular redox state (Rooke et al., 2004).

Table (4): Means \pm standard errors of glutathione peroxidase (GPX) activity during the first three months of pregnancy.

\begin{tabular}{lc}
\hline Experimental groups & GPx activity $(\mu \mathrm{U} / \mathrm{ml})$ \\
\hline Control group & $3.40 \pm 0.40^{\mathrm{c}}$ \\
\hline $0.5 \mathrm{mg}$ Se-supplemented & $8.55 \pm 0.50^{\mathrm{b}}$ \\
\hline $0.7 \mathrm{mg}$ Se-supplemented & $11.50 \pm 1.20^{\mathrm{a}}$ \\
\hline Means within columns with different superscripts are significantly different $(\mathrm{P} \leq 0.05)$.
\end{tabular}

Results in Table (5) showed differences among groups in grease and clean weights of wool samples within $100 \mathrm{~cm}^{2}$ of skin. The means of G.W.S were 26.45, 36.85 and $36.70 \mathrm{gm}$ while the means of C.W.S were $16.25,27.45$ and $28.80 \mathrm{gm}$ for the control group, $0.5 \mathrm{mg} \mathrm{Se}$ supplemented group and $0.7 \mathrm{mg} \mathrm{Se}$ supplemented group respectively. It was clear in this experiment that $\mathrm{Se}$ supplementation to the diet caused an increase in clean weight of wool being greater in the third group $(0.7 \mathrm{mg} \mathrm{Se}-$ supplemented group) during the last two months of pregnancy. McDonald (1975) found significant increases in clean wool weight occurring after Sesupplementation in sheep diet.

Table (5): Means of grease (G.W.S) and clean weights of wool samples (C.W.S) and percentage of contaminants in wool samples $(\mathrm{C} \%)$ during the last two months of pregnancy.

\begin{tabular}{lccc}
\hline Experimental groups & G.W.S (gm) & C.W.S (gm) & C \% \\
\hline Control group & 26.45 & 16.25 & 38.56 \\
\hline $0.5 \mathrm{mg}$ Se-supplemented & 36.85 & 27.45 & 25.50 \\
\hline $0.7 \mathrm{mg}$ Se-supplemented & 36.70 & 28.80 & 21.52 \\
\hline
\end{tabular}

Results in Table (6) show that, there were significant differences $(p \leq 0.05)$ among groups in staple length (STL). The means of STL were $3.45,4.40$ and $5 \mathrm{~cm}$ for the control group, $0.5 \mathrm{mg}$ Se-supplemented group and $0.7 \mathrm{mg}$ Se-supplemented group respectively. The addition of different levels of selenoprotein to the diet of pregnant ewe's increased staple length, the increase was greater in the third group $0.7 \mathrm{mg}$ Se-supplemented group, approximately $(1.55 \mathrm{~cm})$, relative to the control group during the last two months of pregnancy. Godwin, (1975) observed that Se-supplementation increased wool staple length in mature ewes. Growth of wool is influenced by both physiological and nutritional factors. The availability of nutrients to the wool follicle has a big impact on wool growth. This availability is influenced by changes in nutrient partitioning (Brown and Crook, 2005). Also, there were significant differences $(p \leq 0.05)$ among groups in fibre diameter 
(FD). The means of FD were $30.40,33.80$ and $37.70 \mu \mathrm{m}$ for the control group, 0.5 $\mathrm{mg}$ Se-supplemented group and $0.7 \mathrm{mg}$ Se-supplemented group respectively. It was clear in this experiment that $\mathrm{Se}$ supplementation to the diet caused an increase in fibre diameter being greater in the third group $0.7 \mathrm{mg}$ Se-supplemented group, which was approximately $7.30 \mu \mathrm{m}$ relative to the control group during the last two months of pregnancy. Pregnancy and lactation result in depressed wool growth, fibre diameter and tensile strength. Competition for nutrients between wool follicles, maternal tissues and the foetus may cause these changes
(Masters et al., 1993). Depression in wool growth rate associated with pregnancy has been detected as a reduced fibre length growth rate as early as day 21 of gestation (Pearson et al., 1999). Masters et al. (1993) found that plasma concentrations of total free essential amino acids decreased $31 \%$ in the last 3 weeks of pregnancy in ewes fed to maintain conceptus-free live-weight constant. This decline was accompanied by a $43 \%$ decrease in wool growth. Feeding additional protein up to one-third above maintenance had only a limited capacity to restore wool growth in late pregnancy.

Table (6): Means \pm standard errors of staple length (STL) and fibre diameter (FD) during the last two months of pregnancy.

\begin{tabular}{lcc}
\hline Experimental groups & STL $(\mathrm{cm})$ & FD $(\mu \mathrm{m})$ \\
\hline Control group & $3.45 \pm 0.20^{\mathrm{b}}$ & $30.40 \pm 0.95^{\mathrm{c}}$ \\
\hline $0.5 \mathrm{mg}$ Se-supplemented & $4.40 \pm 0.45^{\mathrm{ab}}$ & $33.80 \pm 0.80^{\mathrm{b}}$ \\
\hline $0.7 \mathrm{mg}$ Se-supplemented & $5.00 \pm 0.35^{\mathrm{a}}$ & $37.70 \pm 1.20^{\mathrm{a}}$ \\
\hline Means within columns with different superscripts are significantly different $(\mathrm{P} \leq 0.05)$.
\end{tabular}

Results in Table (7) showed that, there were significant differences $(\mathrm{p} \leq 0.05)$ among groups in staple strength (SST). The means of SST were $24.75,34.35$ and $43.80 \mathrm{~N} /$ Ktex for the control group, 0.5 $\mathrm{mg}$ Se-supplemented group and $0.7 \mathrm{mg}$ Se-supplemented group respectively. It was clear in this experiment that Sesupplementation to the diet caused an increase in staple strength being greater in the third group $0.7 \mathrm{mg}$ Se-supplemented group during the last two months of pregnancy. Results in Table (7) also showed that, there were significant differences $(p \leq 0.05)$ among groups in elongation percentage (ELO \%). The means of ELO \% were 17.25, 31.65 and
$36.65 \%$ for the control group, $0.5 \mathrm{mg} \mathrm{Se}-$ supplemented group and $0.7 \mathrm{mg} \mathrm{Se}$ supplemented group respectively. It was clear in this experiment that $\mathrm{Se}$ supplementation to the diet caused an increase in elongation percentage being greater in the third group $0.7 \mathrm{mg} \mathrm{Se}$ supplemented group during the last two months of pregnancy. Components of staple strength, such as fibre diameter at the point of break, fibre diameter coefficient of variation (FDCV) and rate of change in fibre diameter, are significantly related to staple strength (Adams et al., 1997; Dollin et al., 1995; Hansford and Kennedy, 1990; Thompson et al., 1995). 
Table (7): Means \pm standard errors of staple strength (SST) and elongation percentage (ELO \%) during the last two months of pregnancy.

\begin{tabular}{llc}
\hline Experimental groups & SST (N/Ktex) & ELO \% \\
\hline Control group & $24.75 \pm 1.15^{\mathrm{c}}$ & $17.25 \pm 1.65^{\mathrm{c}}$ \\
\hline $0.5 \mathrm{mg} \mathrm{Se}-$ supplemented & $34.35 \pm 1.35^{\mathrm{b}}$ & $31.65 \pm 1.15^{\mathrm{b}}$ \\
\hline $0.7 \mathrm{mg}$ Se-supplemented & $43.80 \pm 1.75^{\mathrm{a}}$ & $36.65 \pm 1.35^{\mathrm{a}}$ \\
\hline
\end{tabular}

Means within columns with different superscripts are significantly different $(\mathrm{P} \leq 0.05)$.

Table (8): Means \pm standard errors of glutathione peroxidase (GPX) enzyme level of activity during the last two months of pregnancy.

\begin{tabular}{lc}
\hline Experimental groups & $\mathrm{GPx}(\mu \mathrm{U} / \mathrm{ml})$ \\
\hline Control group & $3.95 \pm 0.90^{\mathrm{b}}$ \\
\hline $0.5 \mathrm{mg}$ Se-supplemented & $7.85 \pm 0.70^{\mathrm{a}}$ \\
\hline $0.7 \mathrm{mg}$ Se-supplemented & $10.95 \pm 1.55^{\mathrm{a}}$ \\
\hline Means within columns with different superscripts are significantly different $(\mathrm{P} \leq 0.05)$.
\end{tabular}

Results in Table (8) showed that, there were significant differences among treatments in the level of glutathione peroxidase enzyme activity (GPX) in the blood plasma of pregnant ewes $(\mathrm{p} \leq 0.01)$. It was higher in the $0.7 \mathrm{mg} \mathrm{Se}$ supplemented ewes followed by $0.5 \mathrm{mg}$ Se-supplemented ewes, respectively as compared to the control group. GPX level in the control group was $3.95 \pm 0.90$ $(\mu \mathrm{U} / \mathrm{ml})$, while in the 0.5 Sesupplemented ewes was $7.85 \pm 0.70$ $(\mu \mathrm{U} / \mathrm{ml})$ and the level of GPX in the 0.7 Se-supplemented ewes was $10.95 \pm 1.55$ $(\mu \mathrm{U} / \mathrm{ml})$, during the last two months of pregnancy. Plasma GSH-Px activity contributes to the oxidative defence of animal tissues by catalysing the reduction of hydrogen and lipid peroxides (Halliwell and Chirico, 1993) and is also considered an indicator of oxidative stress (Tüzün et al., 2002). GSH-Px functions in cellular oxidation-reduction reactions to protect the cell membrane from oxidative damage caused by free radicals (Flohe $e t$ al., 1973). Superoxide dismutase (SOD) catalyses the dismutation of superoxide to hydrogen peroxide $\left(\mathrm{H}_{2} \mathrm{O}_{2}\right)$ and it is considered the first defence against prooxidants (Halliwell and Chirico, 1993).

\section{Conclusions}

Addition of selenoproteins to the diet of pregnant ewes is a new practical method to reduce the effect of pregnancy stress on wool produced from ewes, especially during the last two months of pregnancy through the production of GPX which directly protects the follicles cells from damage and increases the cell mitotic division. Further research is required to compare the effect of selenium supplementation in pregnant and nonpregnant ewes.

\section{References}

Banks, R. G. and Brown, D. J. (2009), "Genetic improvement in the Australasian Merino management of a diverse gene pool for changing 
markets", Animal Genetics Resources Journal, Vol. 45, pp. 2936.

Brown, D. J., Crook, B. J. and Purvis I. W. (2005), "Differences in fibre diameter profile characteristics in wool staples from Merino sheep and their relationship with staple strength between years, environments and bloodlines", Australian Journal of Agricultural Research, Vol. 53, pp. 481-491.

Butler, L. G. and Head, G. M. (1992), "The effect of age shearing date and reproduction on seasonal wool growth patterns, staple strength and position of break", Proceedings of Australian Society of Animal Production, Vol. 19, pp. 128-30.

Caffin, R. N. (1980), "The CSIRO staple strength/length system I Design and performance", Journal of the Textile Institute, Vol. 71 No. 2, pp. 65-70.

Corbett, J. L. (1979), "Variation in wool growth with physiological state", in Black, J. L. and Reis, P. J. (Ed.), Physiological and environmental limitations to wool growth, CSIRO, Sydney, Australia, pp. 79-98.

Cottle, D. J. (2000), "Effects of defaunation of the rumen and supplementation with amino acids on the wool production of housed Saxon Merinos 2. Methionine and protected methionine", Australian Journal of Experimental Agriculture, Vol. 28, pp. 179-85.
Dollin, A. E., Schlink, A. C. and Jones, L. N. (1995), "Merino wool fibre structural morphologies and wool strength", Proceedings of the $9^{\text {th }}$ International Wool Textile Research Conference, Vol. 2, pp. 147-53.

Duncan, D. B. (1955), "Multiple ranges and Multiple F test", Biometrics, Vol. 11, pp. 1-42.

Godwin, A. H. (1975), Nutrition for Wool Production, Animal Nutrition Division, Central Sheep and Wool Research Institute, Avikanagar, India.

Halliwell, B. and Chirico, S. (1993), "Lipid peroxidation its mechanism measurement and significance", American Journal of Clinical Nutrition, Vol. 57, pp.715-725.

Hansford, K. A. and Kennedy, J. P. (1990), "The relationship between variation in fibre diameter along staples and staple strength", Proceedings of the $8^{\text {th }}$ International Wool Textile Research Conference, Vol. 1, pp. 590-598.

Johnson, C.L. and Larsen, S.A. (1978), "Clean wool determination of individual fleeces", Journal Animal Science, Vol. 47, pp. 41-45.

Masters, D. G., Stewart, C. A. and Connell, P. J. (1993), "Changes in plasma amino acid pattern's and early wool growth during late pregnancy and early lactation", Australian Journal of Agriculture 
Research, Vol. 44, pp. 945-957.

McDonald, J. (1975), "Selenium response unthriftiness of young Merino sheep in central Victoria", Australian Veterinary Journal, Vol. 51, pp. 433-435.

McNeill, D. M., Slepetis, R., Ehrhardt, R. A., Smith, D. M. and Bell, A. W. (1997), "Protein requirements of sheep in late pregnancy: partitioning of nitrogen between gravid uterus and maternal tissues", Journal Animal Science, Vol. I75, pp. 809816.

Morel, Y. and Barouki, R. (1999), "Repression of gene expression by oxidative stress", Biochemical Journal, Vol. 342, pp. 481-496.

Mortimer, S. I., Atkins, K. D., Semple, S. J. and Fogarty, N. M. (2010), "Predicted responses in Merino sheep from selection combining visually assessed and measured traits", Animal Production Science, Vol. 50, pp. 976-982.

National Research Council (1988), Nutrient requirements of small ruminants (sheep, goats, cervids and new world camelids), National Research Council National Academy Press, Washington, USA.

Oddy, V. H. and Annison, E. F. (1979), "Possible mechanisms by which physiological state influence the rate of wool growth", in Black, J. L. and Reis, P. J. (Ed.), Physiological and environmental limitations to wool growth, CSIRO, Sydney, Australia, pp. 295-309.

Orwin, D. F. G. and Woods J. L. (1980), "Wool fibre diameter and cortex cell type", Journal of The Textile Institute, Vol.71, pp. 6.

Pearson, A. J., Kendall, P. E., Ashby, M. G. and Wildermoth, J. E. (1999), "Fleece production patterns in Romney ewes: effects of photoperiod, pregnancy and lactation", Proceedings of the New Zealand Society of Animal Production, Vol. 59, pp. 30-33.

Reis, P. J., Tunks, D. A. and Munro, S. G. (1992), "Effects of abomasal protein and energy supply on wool growth in Merino sheep", Crop and Pasture Science, Vol. 43 No. 6, pp. 1353-1356.

Rogers, G. E. and Schlink, A. C. (2010), Wool growth and production In International Sheep and Wool Handbook, Nottingham University Press, Nottingham, UK, pp. 373394, 2010.

Rooke, J. A., Robinson, J. J. and Arthur, J. R. (2004), "Effects of vitamin E and selenium on the performance and immune status of ewes and lambs", Journal Agriculture Science, Vol. 142, pp. 253-262.

Rotruck, J. T., Pope, A. L., Ganther, H. E., Swanson, A. B., Hafeman, D. G. and Hoekstra, W. G. (1973), 
"Selenium: Biochemical Role as a Component of Glutathione Peroxidase", Science, Vol. 179, pp. 588-590.

Saudi, E. M. (2015), Effect of supplementing the diet of pregnant ewes with selenoprotein on wool production of the dams and their lambs, Ph.D. Thesis, Al-Azhar University, Faculty of Agriculture, Cairo, Egypt.

Saudi, E. M. (2018), "Evaluating the effect of dietary supplementation selenium and orally administered vitamin $\mathrm{E}$ on wool production in Rahmani sheep", Proceedings of the $1^{\text {st }}$ International Scientific Conference (Agriculture and futuristic Challenges), Vol. 1 No. 1, pp. 240-248.

Snowder, G. D., Lupton, C. J., Shelton, J. M., Kott, R. W., Bradford, G. E., Dally, M. R., Knight, A. D., Glimp, H. A., Stellflug, J. N., Burfening, P. J. and Thompson, P. V. (1997), "Comparison of US fine-wool breeds and Australian Merino F1 crosses I. Wool characteristics and body weight", Sheep Goat Research Journal, Vol. 13, pp. 108-115.
Sordillo, L. M. (2013), "Selenium dependent regulation of oxidative stress and immunity in periparturient dairy cattle", Hindawi Publishing Corporation, Veterinary Medicine International, Vol. 8, pp. 13.

SPSS (1999), Statistical software package for the social sciences, Version 17, SPSS Inc., Armonk, NY, USA.

Thompson, A. N., Hynd, P. I., Peterson, A. D. and Ritchie, A. J. M. (1995), "Fibre strength and the proportion of discontinuous fibres in relation to staple strength in Merino sheep", Proceedings of the $9^{\text {th }}$ International Wool Textile Research Conference, Vol. 2, pp. 143-51. 